\title{
Posttransplantation Vesicoureteral Reflux in Renal Grafts and Their Outcomes in Pediatric Transplantation: Should We Be Afraid?
}

\section{Özgün Araştirma Research Article}

Received/Geliș: 15.07.2019 Accepted/Kabul: 17.11.2019 First Online: 28.09.2021

Demet Alaygut Tepecik Eğitim ve Araştırma Hastanesi Çocuk Nefroloji Kliniği, İzmir, Türkiye

alaygutdemet@gmail.com ORCiD: 0000-0002-2164-4652

E. Soyaltın 0000-0001-9744-7439 Ö. Yavaşcan 0000-0002-3582-5075 F. Mutlubaş 0000-0001-9392-4832 C. Alparslan 0000-0002-7046-8907 Tepecik Eğitim ve Araștırma Hastanesi Çocuk Nefroloji Kliniği, Izmir, Türkiye

E. P. Öncel 0000-0002-6126-4048 Tepecik Eğitim ve Araştırma Hastanesi Çocuk Sağlığı ve Hastalıkları Kliniği, Izmir, Türkiye

i. Sert 0000-0001-5190-9124

C. Tuğmen 0000-0002-2668-5197 Tepecik Eğitim ve Araştırma Hastanesi Genel Cerrahi Kliniği, izmir, Türkiye

T. Özdemir 0000-0002-9555-0835 Tepecik Eğitim ve Araştırma Hastanesi Çocuk Cerrahi Kliniği, Izmir, Türkiye

B. K. Demir 0000-0002-5456-3509 Katip Çelebi Üniversitesi Tıp Fakültesi Çocuk Nefroloji Kliniği, İzmir, Türkiye

Cite as: Alaygut $D$, Soyaltın E, Öncel EP, et al. Cite as: Alaygut $D$, Soyaltin $E$, Oncel EP, et a. Posttransplantation vesicoureteral reflux in renal grafts and their outcomes in pediatric transplantation: Should we be afraid?. Tepeci
Eğit. ve Araşt. Hast. Dergisi. 2021;31(3):409-15.

\author{
Pediatrik Posttransplantasyon Renal Greftlerdeki \\ Vezikoüreteral Reflü ve Sonuçları: Korkmalı mıyız?
}

\author{
Demet Alaygut $\odot$, Eren Soyaltın $\odot$, Elif Perihan Öncel $\odot$, İsmail Sert $\odot$, Cem Tuğmen $\odot$ \\ Tunç Özdemir $\odot$, Önder Yavaşcan $\odot$, Fatma Mutlubaş $\odot$, Caner Alparslan $\odot$ \\ Belde Kasap-Demir ๑
}

\section{ABSTRACT}

Objective: Demographical, pre-transplantation and post-transplantation features and post-treatment results of four pediatric cases, who had vesicoureteral reflux (VUR) in the graft kidney, were discussed.

Methods: Transplantation age, primary diagnosis, VUR to pretransplantation in native kidneys, history of bladder dysfunction, bladder capacity, results of urodynamic studies, donor and its features, induction treatments and ongoing immunosuppressive treatments, acute rejection episodes, CMV and BK infections, VUR grade in the renal graft, DMSA results, treatment type and its outcomes, and the renal graft functions of four patients who underwent kidney transplantation at Tepecik Training and Research Hospital between 2008 and 2016 and for whom VUR was determined via voiding cystourethrography (VCUG) due to recurrent urinary tract infections, were evaluated. Results: All of four cases were female. Their mean transplantation age was 8.7 years (5-16). High grade (Grade 4) VUR was determined in the graft kidney in all but one. DMSA included multiple scar foci apart from one case having low grade VUR. Cases were primarily treated endoscopically and then by open surgery. Spontaneous recovery occurred in one case. Graft dysfunction was not observed in any of the cases.

Conclusion: VUR is an important risk factor in recurrent urinary tract infections after post-transplantation. A special assessment should be done for the patient in the presence of VUR and conservative and surgical treatments should be executed together. It should be remembered that VUR can be spontaneously regressed by the bladder capacity increasing treatments and prophylaxis.

Keywords: Pediatric renal transplantation, vesicoureteral reflux, graft kidney

Öz

Amaç: Greft böbreğinde vezikoüreteral reflü (VUR) olan dört pediatrik olgunun demografik, transplantasyon öncesi ve transplantasyon özellikleri ve tedavi sonrası sonuçları tartışıldı.

Yöntem: 2008-2016 yılları arasında Tepecik Eğitim ve Arastırma Hastanesi'nde böbrek nakli yapılan ve rekürren idrar yolu enfeksiyonu nedeniyle voiding sistouretrografiyi (VCUG) ile graft böbrekte VUR tespit edilen dört hastanın transplantasyon yassı, primer tanısI, nativ böbreklerde pre transplantasyon VUR, mesane disfonksiyonu öyküsü, mesane kapasitesi, ürodinamik çalışmaların sonuçları, donör ve özellikleri, indüksiyon tedavileri ve devam eden immünosüpresif tedaviler, akut rejeksiyon epizotları, CMV ve BK enfeksiyonları, VUR derecesi, DMSA sonuçları, tedavi şekli ve sonuçları ve böbrek greft fonksiyonları değerlendirildi.

Bulgular: Dört vakanın tümü kızdı. Ortalama nakil yașı 8.7 (5-16) yıl idi. Greft böbreklerinden bir tanesi dıșında hepsinde (4. derece) VUR tespit edildi. DMSA, düsük dereceli VUR olan bir olgu dıșında çoklu skar odakları içeriyordu. Olgular öncelikle endoskopik olarak ve daha sonra açık cerrahi ile tedavi edildi. Bir vakada kendiliğinden iyileșme meydana geldi. Hiçbir olguda greft fonksiyon bozukluğu gözlenmedi.

Sonuç: VUR, nakil sonrası tekrarlayan idrar yolu enfeksiyonlarında önemli bir risk faktörüdür. VUR varlığında hasta için özel bir değerlendirme yapılmalıdır. Konservatif ve cerrahi tedaviler birlikte uygulanmalıdır. VUR'un mesane kapasitesi arttıııı tedaviler ve profilaksi ile kendiliğinden gerileyebileceği unutulmamalıdır.

Anahtar kelimeler: Çocuk böbrek nakli, vezikoüreteral reflü, graft böbrek
(C) Telif hakkı T.C. Sağlık Bakanlığı İmir Tepecik Eğit. ve Araşt. Hastanesi. Logos Tıp Yayıncılık tarafindan yayınlanmaktadır. Bu dergide yayınlanan bütün makaleler Creative Commons Atff-GayriTicari 4.0 Uluslararası Lisansı ile lisanslanmıștır.

(C) Copyright Association of Publication of the T.C. Ministry of Health izmir Tepecik Education and Research Hospital. This journal published by Logos Medical Publishing. Licenced by Creative Commons Attribution-NonCommercial 4.0 International (CC BY-NC 4.0) 


\section{INTRODUCTION}

Urologic complications after renal transplantation are the most frequently observed technical side effects and they may have affect the long term allograft survival and allograft loss. In transplanted kidney, vesicoureteral reflux (VUR) is seen frequently among these complications ${ }^{(1)}$. In the patients whom uretero-vesical anastomosis was applied, VUR ratio diagnosis by voiding cystourethrography (VCUG) varies between $10 \%$ and $80 \%{ }^{(2)}$. Besides that in numerous cases, VUR is asymptomatic and it does not require any surgical intervention also does not affect the graft functions or survival in long term. Contrary, approximately $3 \%$ of the cases are symptomatic and graft survival can be significantly decreased by recurrent urinary tract infections $(3,4)$. Especially if the urinary tract infections symptoms are together with VUR, graft damage and even graft loss should be considered important therefore treatment should be done as quick as possible ${ }^{(5,6)}$. In this study it is discussed, the results of the follow-up of four pediatric cases, who had recurrent urinary tract infections after renal transplantation and transplanted kidney reflux via VCUG.

\section{MATERIAL and METHODS}

This is a retrospective study assessing the medical records of renal transplant pediatric patients who had a vesicoureteral reflux (VUR) in renal graft at Tepecik Training and Research Hospital between January 2008 and 31 December 2016. At our center, a total of 72 pediatric renal transplantations were performed within this process. All the transplantations were performed to iliac fossa via extraperitoneal approach. All patients received preoperative cefazolin prophylaxis at the doses suitable for their weights. For urinary continuity, the method preferred by the surgeon for all the patients was extravesical ureteroneocystostomy (Lich Gregoir) method. Double J-stent was inserted to all the patients, which stayed for 4-6 weeks. Intravesical foley catheter was inserted for 4-7 days in average. As prophylaxis, the patients received trimethoprim-sulfamethoxazole (80/400 $\mathrm{mg}$ ) for 6 months and prophylaxis was not discontinued until a current urological abnormality was revealed in the patients having recurrent urinary tract infections. Those patients were followed up weekly in the first month after the transplantation, biweekly until the post-transplantation third month, every three weeks until sixth month, and then monthly within one-year period. Urine culture assessment was made for all the patients during every examination. Voiding cystourethrography (VCUG) was requested from the patients who had $\geq 3$ urinary tract infection.

After this follow-up; files of the four patients having VUR in renal graft were assessed retrospectively. Follow-up of all the four cases continued at our posttransplantation center. Before renal transplantation the following variables were taken into consideration: transplantation age, gender, etiology of end-stage renal disease (primary diagnosis) VUR in native kidneys, urinary tract infections (UTI) of pretransplantation period, voiding dysfunction histories, bladder capacities, urodynamic study results, VUR treatment in native kidneys, renal replacement therapies and its duration, donor type and their ages, cold ischemia time, mismatch numbers, induction therapy with monoclonal (basiliximab) and polyclonal antibodies (antithymocyte globulin ATG), type of immunosuppression, episodes of acute rejection types and their times, CMV and BK virus infections, VUR grade in renal grafts, posttransplantation DMSA results, treatments used for graft VUR, and follow-up duration. In order to assess renal allograft function, we used first month creatinine, estimated glomerular filtration (eGFR as Schwartz) levels, last creatinine and eGFR and proteinuria. Also, the number of infections after post-transplantation, and type of infection (upper UTI, lower UTI, asymptomatic bacteriuria, urosepsis) of the patients were assessed. Upper UTI was characterized by the presence of significant bacteriuria, fever $>38^{\circ} \mathrm{C}$, and/or graft pain and/or acute graft function impairment ${ }^{(7)}$. Lower UTI was characterized by the presence of bacteriuria and clinical manifestations of dysuria, frequency or 
urinary urgency and fever $<38^{\circ} \mathrm{C}^{(8)}$. Asymptomatic bacteriuria was defined as isolation of bacterial strain in quantitative counts of $\geq 10^{5}$ colony forming units (CFU) in clean-catch voided urine specimens in the absence of any symptoms of lower or upper UTI (including leukocyturia) or $<10^{5} \mathrm{CFU}$ in patients treated with antibiotics or $\geq 10^{2} \mathrm{CFU}$ in a single catheterized urine specimen ${ }^{(9)}$. The diagnosis of urosepsis was established when simultaneous positive blood and urine cultures were obtained with the isolation of the same bacterial strain.

\section{RESULTS}

All the cases were female. Their mean transplantation age was 8.75 year ${ }^{(5-16)}$. Case 1 had infantile nephrotic syndrome, case 2 had nephronophthisis, case 3 had VUR and dysplastic kidney, and case 4 had end-stage renal failure due to Ig A nephropathy. Case 3 had bilateral grade 3 VUR in native kidneys and ureteroneocystostomy (UNC) was applied to the patient in the pre-transplantation period. In Case 4, grade 2 VUR was determined in the asymptomatic right native kidney during the transplantation preparations and while the double J catheter was removed after the transplantation, endoscopic surgery was applied to the native kidney during cystoscopy. Other two cases had no VUR to the native kidney. When pre-transplantation was assessed in terms of UTIs, the history was positive in Case 3. In terms of bladder dysfunction, Case 1 and 3 had symptoms and Case 1 was receiving oxybutynin treatment. When the expected bladder capacities were calculated according to (age +1$) \times 30 \mathrm{ml}(10)$, the measured bladder capacity was low in Case 1 and Case 3. Thus, urodynamic examination was performed in the pre-transplantation period for these two cases. While normal compliance bladder with high pressure was determined in Case 1, the reduced compliance bladder with high pressure was determined in Case 3. As renal replacement treatment, peritoneal dialysis (PD) treatment was applied to the first 3 cases. Case 4 underwent preemptive transplantation. Duration of PD applied to these patients was minimum 3 months and maximum 76 months. While Case 1 underwent transplantation from cadaveric donor with 5 mismatches, Case 3 underwent transplantation from cadaveric donor 3 mismatches. Case 2 and Case 4 were transplanted from a live donor (mother-father). Cold ischemia period was 56.25 minutes in average. As the induction therapy, one case (Case 1 ) received ATG and steroid, others received basiliximab and steroid. Immunosuppressive treatment regimen was triple (steroid, tacrolimus and mycophenolate sodium/ mycophenolic acid) in all the patients. Case 4 had cellular type acute rejection in the 4th posttransplantation month. When assessed in terms of CMV /BK infection, while Case 1 had both infections and Case 3 had only CMV infection. All the cases had UTI that started in the first 6th months of posttransplantation. These infections were recurrent pyelonephritis, cystitis, andasymptomatic bacteriuria. VCUG taken for infections showed reflux as advanced stage (grade 4) in the first 3 cases and as grade 2 in case 4 . As the treatment, prophylaxis was applied to the cases and oxybutynin, endoscopic surgery and extravesical UNC (Lich Gregoir) were applied to the cases with bladder dysfunction. Only in Case 2, reflux showed a spontaneous recovery without any surgical treatment. Case 3 was followed up again due to the continuation of reflux after UNC and second UNC was planned if DMSA progression occurred. Figure 1 shows the VCUG images of the patients. In DMSA taken between the infections, scar was determined in lower and upper pole in Case 1 and 3 and scar was determined in the lower pole in case 2. DMSA of Case 4 was normal. At the end of a mean 37.2-month follow-up; creatinine values of all the patients were at the basal creatinine value. Table 1 shows the demographic, pre-transplantation and posttransplantation features of the patients.

\section{DISCUSSION}

In this paper it is reported, four renal transplantation pediatric cases, who had different diagnoses and determined reflux in the renal graft. Urological complications occurring after renal transplantation is an important problem causing increased morbidity 
Table 1. Demographic, pretransplantation and posttransplantation features of patients.

\begin{tabular}{|c|c|c|c|c|}
\hline & Case 1 & Case 2 & Case 3 & Case 4 \\
\hline Age (year)* & 5 & 8 & 6 & 16 \\
\hline Gender & $\mathrm{F}$ & $\mathrm{F}$ & $\mathrm{F}$ & $\mathrm{F}$ \\
\hline Primary diagnosis & $\begin{array}{l}\text { Infantil nephrotic } \\
\text { syndrome }\end{array}$ & Nephronophtysis & $\begin{array}{l}\text { VUR+ Dysplastic } \\
\text { kidney }\end{array}$ & IgA nephropathy \\
\hline $\begin{array}{l}\text { Pretx VUR (in nativ } \\
\text { kidney) }\end{array}$ & No & No & $\begin{array}{l}\text { Bilaterally grade } 3 \\
\text { VUR }\end{array}$ & Right grade 2 \\
\hline Pretx UTI & No & No & + & No \\
\hline $\begin{array}{l}\text { Pretx voiding } \\
\text { dysfunction }\end{array}$ & + & No & + & No \\
\hline Bladder volume & $150 \mathrm{ml} \downarrow$ & $220 \mathrm{ml} \downarrow$ & $180 \mathrm{ml} \downarrow$ & $480 \mathrm{ml}$ \\
\hline Urodynamic study & High pressure & No & $\begin{array}{l}\text { High pressure, } \\
\text { decreased } \\
\text { complians }\end{array}$ & No \\
\hline $\begin{array}{l}\text { Native VUR } \\
\text { treatment }\end{array}$ & - & - & Pretx UNC & $\begin{array}{l}\text { Posttx first month } \\
\text { sting }\end{array}$ \\
\hline $\begin{array}{l}\text { RRT type/ duration } \\
\text { (month) }\end{array}$ & PD, 24 & PD, 3 & PD,76 & No \\
\hline Donor type/age & Cadaveric, 50 & Living, mother, 31 & Cadaveric, 30 & Living, father, 42 \\
\hline $\begin{array}{l}\text { Cold ischemia time } \\
\text { (min) }\end{array}$ & 45 & 60 & 55 & 65 \\
\hline Mismatch number & 5 & 3 & 3 & 1 \\
\hline Induction therapy & ATG, Str & Basiliximab, Str & Basiliximab, Str & Basiliximab, Str \\
\hline $\begin{array}{l}\text { Immunsupressive } \\
\text { treatment }\end{array}$ & Str, Tac, Myc & Str, Tac, Myc & Str, Tac, Myc & Str, Tac, Myc \\
\hline $\begin{array}{l}\text { Acute rejection/ } \\
\text { time (month)** }\end{array}$ & No & No & No & Cell mediated/ 4 \\
\hline CMV/BK infection & $+/+$ & $-1-$ & $+/-$ & $-1-$ \\
\hline Postrenal UTIs & 5 AGPN, 3 Cyst & 3 AGPN, 2 Cys, 2 AB & $\begin{array}{l}3 \text { AGPN, } 5 \text { Cys, } 3 \\
A B\end{array}$ & 3 AGPN \\
\hline VUR in renal graft & Grade 4 & Grade 4 & Grade 4 & Grade 2 \\
\hline Posttx DMSA & $\begin{array}{l}\text { Scarring in upper } \\
\text { and lower pole in } \\
\text { graft }\end{array}$ & $\begin{array}{l}\text { Scarring in lower } \\
\text { pole in graft }\end{array}$ & $\begin{array}{l}\text { Scarring in upper } \\
\text { and lower pole in } \\
\text { graft }\end{array}$ & Normal \\
\hline $\begin{array}{l}\text { Treatment and } \\
\text { outcomes }\end{array}$ & $\begin{array}{l}\text { Prophylaxis, } \\
\text { Oxybutinin, Sting } 2 \\
\text { time, UNC } \rightarrow \\
\text { control VCUG : } \\
\text { Normal }\end{array}$ & $\begin{array}{l}\text { Prophylaxis, } \\
\text { Oxybutinin, spontan } \\
\text { regression } \rightarrow \text { control } \\
\text { VCUG: normal }\end{array}$ & $\begin{array}{l}\text { Prophylaxis, } \\
\text { Oxybutinin, Sting } 2 \\
\text { time, UNC } \rightarrow \\
\text { control VCUG: } \\
\text { grade } 4 \text { VUR } \\
\end{array}$ & $\begin{array}{l}\text { Prophylaxis } \\
\text { UNC } \rightarrow \text { control } \\
\text { VCUG: normal }\end{array}$ \\
\hline $\begin{array}{l}\text { Posttx 1. month } \\
\text { creatinine }(\mathrm{mg} / \mathrm{dl}) \\
\text { and eGFR }\end{array}$ & $0.8 / 63.9$ & $0.7 / 80.9$ & $0.8 / 72.1$ & $1.1 / 79$ \\
\hline $\begin{array}{l}\text { Last creatinine } \\
(\mathrm{mg} / \mathrm{dL}) \text { and eGFR }\end{array}$ & $0.9 / 70$ & $0.7 / 102$ & $0.8 / 82.5$ & $1.2 / 72.8$ \\
\hline Last proteinuria & - & - & - & - \\
\hline $\begin{array}{l}\text { Follow-up time } \\
\text { (month) }\end{array}$ & 36 & 65 & 36 & 12 \\
\hline
\end{tabular}

and hospitalization. Frequency varies between $2.9 \%$ and $21 \%$ in different centers and one of the most frequent complication is related to ureter ${ }^{(11)}$. VUR, encountered as a complication, is an important reason of UTIs in the post-transplant period. In early and long term, its negative effect on graft survival and renal functions is known ${ }^{(1)}$. Real incidence of VUR after renal transplantation is not known. VUR ratio shown by applying VCUG due to recurrent UTIs is $2 \%{ }^{(12,13)}$. This shows that VUR can remain as asymptomatic in most of the cases. However, all of our cases were the patients to whom VCUG was applied due to recurrent UTI. Double-J catheter was routinely applied to all the patients for 4-6 weeks however catheter-related UTI was not observed in any of the cases. Respecting the VUR variation grades, grade 4 was in 3 of our cases. Jung Go et al., reported in their study VUR ratio as $63 \%$ and $25 \%$ as 

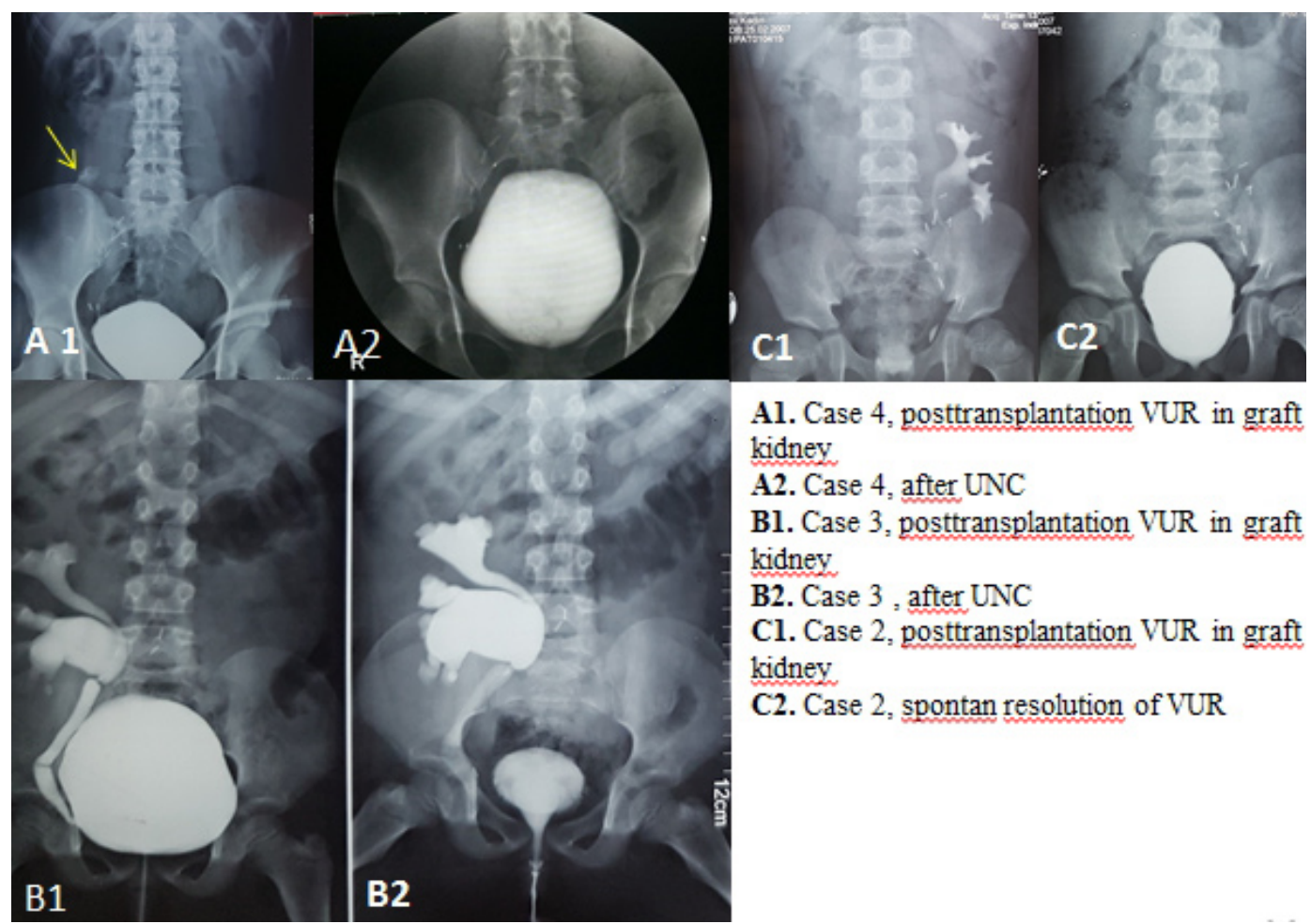

Al. Case 4, posttransplantation VUR in graft kidney

A2. Case 4, after UNC

Bl. Case 3, posttransplantation VUR in graft kidney

B2. Case 3, after UNC

Cl. Case 2, posttransplantation VUR in graft kidney

C2. Case 2, spontan resolution of VUR

Figure 1.

grade 3 and higher ${ }^{(14)}$. Implantation was applied to our patients via the extravesical Lich-Gregoir method. Regarding the VUR formation, Borrera et al., stated that VUR would not develop anti-reflux mechanism in case a long submucosal tunnel is established via Lich Gregoir method. Although this method is not exactly applied in our center, the distance is about 3 $\mathrm{cm}$ and it is considered to provide a sufficient length (15). In the development of VUR, the structure of the bladder is also important other than the surgical technique. It is not easy and even difficult to establish a long submucosal tunnel in the patients having small-capacity atrophic thin detrusor muscle structure. In the study conducted by Takamitsu Inoue et al., investigating the effect of pre-transplant bladder capacity and dialysis duration on posttransplantation VUR, they found that long-term dialysis caused anuria and the bladder capacity would decrease. They stated that VUR prevalence was higher in those undergoing dialysis for up to 60 months having a bladder pre-transplant capacity below of $130 \mathrm{~mL}$. Of course, this study was done in adult patients and the types of renal replacement treatment of those patients were not specified ${ }^{(16)} .3$ of our patients having a low bladder capacity were in the PD program. However, it was known that two of the cases (case 1,3 ) had urination dysfunction before the transplantation and they were receiving oxybutynin treatment due to their low bladder capacities. One case (case 3 ) was receiving the PD treatment for 76 months. Thus, a small pre-transplant bladder capacity depending on a long dialysis period was not a suitable reason for our patient group.

Although open surgical reimplantation is the reference treatment for symptomatic VUR with a success ratio of $83-100 \%$, this procedure is difficult and has significant morbidities ${ }^{(17,18)}$. Endoscopic treatment is the minimal invasive procedure and it has $10 \%$ morbidity and $60-86 \%$ success ratio. In our center, primarily endoscopic treatment is preferred for the post-transplant VUR treatment. If endoscopic treatment is unsuccessful, UNC is applied via open surgery (via Lich Gregoir technique). Endoscopic treatment was applied twice in Case 1 and Case 3 and then, UNC was applied when no success was 
obtained. DX_HA (Deflux) was used as the bulking agent in the endoscopic treatments and 3 months after every treatment, a control VCUG was done. DX_HA is the most frequently used bulking agent and its superiority in the literature against others is known ${ }^{(2)}$. However, in some studies, it is reported that VUR grade is more important in terms of clinical success ${ }^{(19,20)}$. Success ratio is especially higher at low grades (grade I and II). All of our patients to whom endoscopic treatment was applied, had high-grade reflux and success could not be provided by this treatment. Then, treatment success could not be achieved in one of our cases as open surgery was applied (Case 3). Upon following the patient and observing a progression in DMSA, open surgery was planned one more time. Case 2 showed spontaneous recovery without requiring any surgical interventions. Only oxybutynin, prophylaxis and urination recommendations were given. It was thought that this situation could be related to the increasing posttransplantation bladder capacity of the patient.

VUR is a risk factor defined for post-transplantation recurrent and symptomatic UTI. It may cause acute pyelonephritis and reflux nephropathy as in the primary reflux disease ${ }^{211}$. In long-term, the effect of urinary tract infections on the graft functions is not known exactly. Pelle et al., argued that acute graft pyelonephritis (AGPN) was an independent risk factor for the decrease in the renal functions. There are some studies not indicating this relationship ${ }^{(22)}$. It is argued that not only asymptomatic bacteriuria, but also AGPN do not affect the renal functions in long term ${ }^{(23)}$. Also UTI has an indirect effect on bacteremia, acute rejection or CMV infection ${ }^{(24,25)}$. Only one of our patients with VUR had AGPN (case 4), others had both AGPN and cystitis and asymptomatic bacteriuria attacks. The patients with AGPN were hospitalized and treated by widespectrum antibiotics and cystitis and asymptomatic bacteriuria attacks were treated by oral antibiotics.

Risk factors such as female gender of all patients, acute rejection episodes and increasing immunosuppression, use of ATG in one case and
CMV infection in two cases make us think that some infections in these patients may not be related to VUR alone. Acute rejection in one patient, ATG use in one patient and $\mathrm{CMV}$ infection during the follow-up in two patients were observed as cause.

In the DMSA images of the patients taken after infection, multiple scars were determined in all the cases except for one (case 4). There was a previous opinion in pediatric VUR studies that infections would not develop scar in native kidney after the age of 5. Thus, it was thought that scars would not develop in adult kidneys ${ }^{(26)}$. However, the review of Abbot KC et al. published in 2004 about the possibility of serious effects of late-term ( $\geq 3$ months) infections has changed this view. When Dupond et al., assessed 32 patients having late-period post-transplantation symptomatic and asymptomatic UTI for 3 or more times in a year, they showed that $75 \%$ of them (24 patients) have scars shown by DMSA SPECT, $15 \%{ }^{(47)}$ had VUR shown by VCUG, and 13 of these 15 patients $(87 \%)$ had accompanying scars. No relationship was found between the scar density and count and the VUR grade and in this series, graft survival was not affected ${ }^{(26)}$. When the patients were assessed in the 1st post-transplant month and their clinical visits in terms of serum creatinine values, eGFR and proteinuria, no graft function loss was observed.

Consequently, we want to highlight the following matters with these relatively small number (four) patients: UTI are common infections in posttransplantation period and they should be treated aggressively. Frequently recurrent infections may be related to the acute rejection episode of the patient, use of increased immunosuppressive treatment and the CMV infection. However, it should be remembered that VUR is an important risk factor and it should be examined by VCUG. Special assessment should be performed for the patient in the presence of VUR and it should be remembered that VUR may regress by urination recommendations, treatments increasing the bladder capacity and prophylaxis. Surgical treatment options should always be kept in mind and timing should be correctly decided. The effect of 
UTI and VUR, which are recurrent in long term, on the graft functions is still arguable.

Ethics Committee Approval: This article does not contain any studies with human participants or animals performed by any of the authors.

\section{Conflict of Interest: None.}

\section{Funding: None.}

Informed Consent: Obtained from patients families.

\section{REFERENCES}

1. Molenaar NM, Minnee RC, Bemelman FJ, Idu MM. Vesicoureteral Reflux in Kidney Transplantation. Prog Transplant. 2017;27(2):196-9. [CrossRef]

2. Akiki A, Boissier R, Delaporte V, Maurin C, Gaillet S, Karsenty G, Coulange C, Lechevallier E. Endoscopic treatment of symptomatic vesicoureteral reflux after renal transplantation J Urol. 2015;193(1):225-9. [CrossRef]

3. Ohba K, Matsuo $M$, Noguchi $M$, Nishikido $M$, Koga $S$, Kanetake H, Nazneen A, Liu D, Razzaque MS, Taguchi T. Clinicopathological study of vesicoureteral reflux (VUR)associated pyelonephritis in renal transplantation. Clin Transplant. 2004;18 Suppl 11:34-8. [CrossRef]

4. Mastrosimone S, Pignata G, Maresca MC, Calconi G, Rabassini A, Butini R, Fandella A, Di Falco G, Chiara G, Caldato C, et al. Clinical significance of vesicoureteral reflux after kidney transplantation. Clin Nephrol. $1993 ; 40(1): 38-45$.

5. Dupont PJ, Psimenou E, Lord R, Buscombe JR, Hilson AJ, Sweny $P$. Late recurrent urinary tract infections may produce renal allograft scarring even in the absence of symptoms or vesicoureteric reflux. Transplantation. 2007;84(3):351-5. [CrossRef]

6. Abbott KC, Swanson SJ, Richter ER, Bohen EM, Agodoa LY, Peters TG, Barbour G, Lipnick R, Cruess DF. Late urinary tract infection after renal transplantation in the United States. Am J Kidney Dis. 2004;44(2):353-62. [CrossRef]

7. Hoberman A, Charron M, Hickey RW, Baskin M, Kearney DH, Wald ER. Imaging studies after a first febrile urinary tract infection in young children. N Engl J Med. 2003;348(3):195. [CrossRef]

8. Schlager TA, Whittam TS, Hendley JO, Hollis RJ, Pfaller MA, Wilson RA, Stapleton A. Comparison of expression of virulence factors by Escherichia coli causing cystitis and E. coli colonizing the periurethra of healthy girls. J Infect Dis. 1995;172(3):772. [CrossRef]

9. Nicolle LE. Asymptomatic bacteriuria. Curr Opin Infect Dis. 2014;27(1):90-6. [CrossRef]

10. Austin PF, Bauer SB, Bower W, et al. The standardization of terminology of lower urinary tract function in children and adolescents: update report from the Standardization Committee of the International Children's Continence Society. J Urol. 2014;191(6):1863-5.e13. [CrossRef]

11. Sözen H, Özen O, Fidan K, Söylemezoğlu O, Dalgıç A. Outcome of the Double-J Stent Placement in Pediatric Kidney Transplant: A Single Center Experience. Exp Clin Transplant.
2017 Jun 16. [CrossRef]

12. Moreira P, Parada B, Figueiredo A, Maia N, Nunes P, Bastos C, Mota A. Comparative study between two techniques of ureteroneocystostomy: Taguchi and Lich-Gregoir. Transplant Proc. 2007;39(8):2480-2. [CrossRef]

13. Secin FP, Rovegno AR, Marrugat RE, Virasoro R, Lautersztein GA, Fernandez H. Comparing Taguchi and Lich-Gregoir ureterovesical reimplantation techniques for kidney transplants. J Urol. 2002;168(3):926-30. [CrossRef]

14. Jung GO, Chun JM, Park JB, Choi GS, Kwon CH, Joh JW, Lee SK, Kim SJ. Clinical significance of posttransplantation vesicoureteral reflux during short-term period after kidney transplantation. Transplant Proc. 2008;40(7):2339-41. [CrossRef]

15. Barrero R, Fijo J, Fernandez-Hurtado $\mathrm{M}$ et al. Vesicoureteral reflux after kidney transplantation in children. Pediatr Transplant 2007;11:498 [CrossRef]

16. Inoue $\mathrm{T}$, Satoh $\mathrm{S}$, Saito $\mathrm{M}$, et al. Correlations between pretransplant dialysis duration, bladder capacity, and prevalence of vesicoureteral reflux to the graft. Transplantation. 2011;92(3):311-5. [CrossRef]

17. Hau HM, Tautenhahn HM, Schmelzle M et al. Management of urologic complications in renal transplantation: a singlecenter experience. Transplant Proc 2014;46:1332. [CrossRef]

18. Lehman K, Müller MK, Schiesser $M$ et al. Treatment of ureteral complications after kidney transplantation with native ureteropyelostomy reduces the risk of pyelonephritis. Clin Transplant 2011;25:201. [CrossRef]

19. Mallet R, GameX, Mouzin M et al. Symptomatic vesicoureteral reflux in kidney transplantation: results of endoscopic injections of Teflon and Predictive factors for success. Prog Urol. 2003;13:598.

20. Elder JS, Diaz M, Caldamone AA et al. Endoscopic therapy for vesicoureteral reflux: a meta-analysis. I. Reflux resolution and urinary tract infection. J Urol 2006;175:716. [CrossRef]

21. Turunç V, Eroğlu A, Tabandeh B, Erol A. Comparison of Surgical Correction Techniques for Post-Renal Transplantation Vesicoureteral Reflux. Transplant Proc. 2017;49(3):512-6. [CrossRef]

22. Pellé G, Vimont S, Levy PP, Hertig A, Ouali N, Chassin C, Arlet $G$, Rondeau $E$, Vandewalle A. Acute pyelonephritis represents a risk factor impairing long-term kidney graft function. Am J Transplant. 2007;7(4):899-907. [CrossRef]

23. Gołębiewska JE, Dębska-Ślizień A, Rutkowski B. Urinary tract infections during the first year after renal transplantation: one center's experience and a review of the literature. Clin Transplant. 2014;28(11):1263-70. [CrossRef]

24. Silva M Jr, Marra AR, Pereira CA, Medina-Pestana JO, Camargo LF. Bloodstream infection after kidney transplantation: epidemiology, microbiology, associated risk factors, and outcome. Transplantation. 2010;90(5):581-7. [CrossRef]

25. Audard V, Amor M, Desvaux D, Pastural M, Baron C, Philippe $R$, Pardon A, Dahmane D, Lang P, Grimbert P. Acute graft pyelonephritis: a potential cause of acute rejection in renal transplant. Transplantation. 2005;80(8):1128-30. [CrossRef]

26. Dupont PJ, Psimenou E, Lord R, Buscombe JR, Hilson AJ, Sweny $P$. Late recurrent urinary tract infections may produce renal allograft scarring even in the absence of symptoms or vesicoureteric reflux. Transplantation. 2007;84(3):351-5. [CrossRef] 